\title{
Vascular epiphytes of the Atlantic Forest in the Sinos River basin, state of Rio Grande do Sul, Brazil: richness, floristic composition and community structure
}

\author{
Barbosa, MD. ${ }^{a}$, Becker, DFP. ${ }^{a}$, Cunha, S. ${ }^{a}$,Droste, A. ${ }^{a}$ and Schmitt, JL. ${ }^{a *}$ \\ aPrograma de Pós-Graduação em Qualidade Ambiental, Universidade Feevale, \\ Rodovia RS 239, 2755, Vila Nova, CEP 93525-075, Novo Hamburgo, RS, Brazil \\ *e-mail: jairols@feevale.br
}

Received: May 24, 2013 - Accepted: August 26, 2013 - Distributed: May 31, 2015

(With 1 figure)

\begin{abstract}
The Atlantic Forest, which has a vast epiphytic richness, is a priority area for preservation, listed as one of the five most important world hotspots. Vascular epiphyte richness, composition and community structure were studied in two fragments, one of the ombrophilous ( $29^{\circ} 43^{\prime} 42^{\prime \prime} \mathrm{S}$ and $\left.50^{\circ} 22^{\prime} 00^{\prime \prime} \mathrm{W}\right)$ and the other of the seasonal $\left(29^{\circ} 40^{\prime} 54^{\prime \prime} \mathrm{S}\right.$ and $51^{\circ} 06^{\prime} 56^{\prime} \mathrm{W}$ ) forest, both belonging to the Atlantic Forest biome in the Sinos River basin, Rio Grande do Sul, Brazil. In each fragment, 40 trees, divided into four ecological zones, were analyzed. In each zone, the occurrence of the species was recorded, and the importance value of each species was calculated according to the frequency of phorophytes and intervals, and cover scores. The Shannon index was calculated for the two communities. In the fragment of the ombrophilous forest (F1), 30 epiphytic species were recorded, and in the seasonal forest (F2), 25. The highest importance value was found for Microgramma squamulosa (Kaulf.) de la Sota in both fragments. The diversity indexes for F1 $\left(\mathrm{H}^{\prime}=2.72\right)$ and F2 $\left(\mathrm{H}^{\prime}=2.55\right)$ were similar and reflected the subtropical location of the areas. The decrease in mean richness in both fragments in zone 3 (internal crown) to zone 4 (external crown) may be associated with time and space availability for epiphyte occupation and microclimate variations. Exclusive species were found in the areas, which suggest that a greater number of preserved fragments may result in a greater number of preserved epiphytic species in the Sinos River basin.
\end{abstract}

Keywords: vertical distribution, epiphytism, phytosociology, floristic diagnostic, southern Brazil.

\section{Epífitos vasculares em Floresta Atlântica da bacia do Rio dos Sinos, estado do Rio Grande do Sul, Brasil: riqueza, composição florística e estrutura comunitária}

\begin{abstract}
Resumo
A Floresta Attântica apresenta uma grande riqueza de epífitos e é considerada uma área prioritária para preservação listada entre os cinco mais importantes hotspots mundiais. A riqueza, a composição e a estrutura comunitária de epífitos vasculares foram estudadas em um fragmento de floresta ombrófila (29 $43^{\prime} 42^{\prime \prime} \mathrm{S}$ e $\left.50^{\circ} 22^{\prime} 00^{\prime \prime} \mathrm{O}\right)$ e outro de floresta

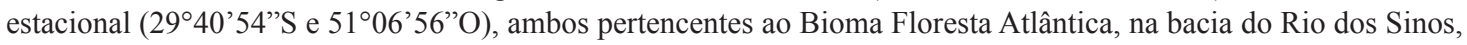
Rio Grande do Sul, Brasil. Em cada fragmento foram analisadas 40 árvores divididas em quatro zonas ecológicas. Em cada zona, foi registrada a ocorrência das espécies e o valor de importância de cada uma delas foi calculado a partir da frequência nos forófitos e nos intervalos e das notas de cobertura. O índice de Shannon foi aplicado para as duas comunidades. No fragmento de floresta ombrófila (F1) foram registradas 30 e no de floresta estacional (F2) 25 espécies epifíticas. O maior valor de importância foi observado para Microgramma squamulosa (Kaulf.) de la Sota, em ambos os fragmentos. Os índices de diversidade para o $\mathrm{F} 1\left(\mathrm{H}^{\prime}=2,72\right)$ e o $\mathrm{F} 2\left(\mathrm{H}^{\prime}=2,55\right)$ foram próximos e refletem a posição geográfica mais subtropical das áreas. A diminuição na riqueza média em ambos os fragmentos da zona 3 (copa interna) para a zona 4 (copa externa) pode estar relacionada com a disponibilidade de tempo e de espaço para a ocupação de epífitos e com variações microclimáticas. Considerando que as áreas apresentaram espécies exclusivas, ficou evidenciado que um maior número de fragmentos conservados conduzirá à manutenção de um maior número de espécies epifíticas na bacia do Rio dos Sinos.
\end{abstract}

Palavras-chave: distribuição vertical, epifitismo, fitossociologia, diagnóstico florístico, sul do Brasil. 


\section{Introduction}

Epiphytes account for a substantial part of forest diversity and up to $10 \%$ (Kress, 1986) to $50 \%$ (Kersten and Silva, 2005) of all vascular plants in tropical forests. The Atlantic Forest, listed as one of the five most important world hotspots, has 20,000 species of vascular plants (Myers et al. 2000), and 3,000 to 4,000 of them are epiphytic (Kersten, 2010). In the state of Rio Grande do Sul, Brazil, the Atlantic Forest has been reduced to only $7.48 \%$ of its original area (Fundação SOS Mata Atlântica and INPE, 2011), and ombrophilous and seasonal forests are found in some of the phytoecological regions of this biome.

Epiphytism has an important ecological function in forest communities and participates in the preservation of biological diversity by providing nutritional resources and specialized microenvironments for the fauna in the crown and by participating in nutrient cycling mechanisms; it is, therefore, considered as a local biodiversity amplifier (Nadkarni, 1984; Gentry and Dodson, 1987; Lugo and Scatena, 1992; Waechter, 1992; Rocha et al., 2004). Knowledge on vascular epiphyte composition and community structure has been used to define quality and environmental characteristics (Krömer et al., 2007). Epiphytic plants have been used to classify the successive regeneration stages of plant formations in the Atlantic Forest of Rio Grande do Sul, according to the CONAMA Resolution no. 33/94 (Brasil, 2012).

The spatial distribution of richness and the composition of the epiphytic flora may be affected by several factors at different scales and directions, such as the regional mosaic of plant types, the vertical profile of the forests, the characteristics of phorophytes and the climate conditions inside the forest (Gentry and Dodson, 1987; Nieder et al., 1997; Schmitt and Windisch, 2005; 2010; Waechter, 2006). Some of the microclimate factors that may affect vertical distribution are humidity, which tends to decrease from the ground to the apex, and luminosity, which increases in the same direction (Lüttge, 1989; Ter Steege and Cornelissen, 1989).

In general, epiphytes are extremely diversified and profuse in dense ombrophilous forests when compared with deciduous and semi-deciduous seasonal forests (Rambo, 1954; Klein, 1975; Roderjan et al., 2002), a similar distribution to that of fern richness (Sehnem, 1977; 1979). In the southern region of Brazil, studies have been conducted with different vegetation types, including coastal plains (Waechter, 1986; 1992; 1998; Kersten and Silva, 2001; Gonçalves and Waechter, 2003; Staudt et al., 2012; Becker et al., 2013), semi-deciduous (Aguiar et al., 1981; Borgo et al., 2002; Dettke et al., 2008) and deciduous (Rogalski and Zanin, 2003) seasonal forests, dense (Blum et al., 2011) and mixed (Borgo and Silva, 2003; Hefler and Faustioni, 2004; Schmitt et al., 2005; Brustulin and Schmitt, 2008; Buzatto et al., 2008; Bonnet et al., 2009; Kersten and Kuniyoshi, 2009; Kersten et al., 2009) ombrophilous forests, riparian forests (Giongo and Waechter, 2004) and areas of transition from semi-deciduous seasonal to mixed ombrophilous forests (Bonnet et al., 2010, 2011).

Among the studies that compared the epiphytism in different areas, Barthlott et al. (2001) analysed secondary and primary vegetations in a humid Montana forest in Venezuela. Flores-Palacios and García-Franco (2008) compared the relationship between tree size and species richness in forest and pastureland trees. Krömer et al. (2007) studied the vertical stratification in a submontane and montane forest of the Bolivian Andes. In Brazil, MeniniNeto et al. (2009) analysed the angiosperm epiphytes in forest fragments in southeastern Minas Gerais. Bataghin et al. (2010) compared the distribution of epiphytes in three sites with different degrees of disturbance in a semi-deciduous seasonal forest in the Floresta Nacional de Ipanema, in the state of São Paulo. In the state of Paraná, Kersten and Kuniyoshi (2009) evaluated epiphyte composition and distribution in eight areas of the mixed ombrophilous forest of the Alto Iguaçu river basin. In the same forest type, Bonnet et al. (2009) evaluated the vascular epiphyte diversity in four sites from the Corredor Araucária, relating it to factors of environmental degradation and forest characteristics. Bonnet et al. (2010) analysed three sections of riparian vegetation in the Tibagi River to evaluate the composition, distribution and association with environmental factors in each area. The present study evaluated the richness, composition and community structure of vascular epiphytes in two fragments in the upper and lower sections of the Sinos River basin, belonging to ombrophilous and semi-deciduous forests, respectively.

\section{Material and Methods}

\subsection{Study area}

This study was conducted in two secondary forest fragments located in the Sinos River basin in the state of Rio Grande do Sul, Brazil: (a) fragment 1 (F1) was in the upper section of the basin, in a rural area, next to the source of the Sinos River, in the municipality of Caraá (2943'42'S and 50²2'00'W; $408.1 \mathrm{~m}$ alt.); 60 ha of predominantly dense ombrophilous forest with some remaining mixed ombrophilous forest; (b) fragment 2 (F2) was in the lower section of the basin, in the municipality of Novo Hamburgo (2940'54'S and 51 ${ }^{\circ} 06$ '56”'W; $16.4 \mathrm{~m}$ alt.), in the Henrique Luís Roessler park, formally declared a Preservation Area in 2009, in the category of Relevant Area of Ecological Interest. This park is in the urban area of the town and has an area of 54.4 ha of fields and forests (Rosa, 2010) classified as lowlands semi-deciduous seasonal forest (Teixeira et al., 1986). The climate in the region of the two fragments is $C f a$ according to the Köppen classification: temperate with rainfall regularly distributed over the year; and temperature of the hottest month higher than $22^{\circ} \mathrm{C}$ (Moreno, 1961). In Caraá (F1), rainfall is about $1,600 \mathrm{~mm}$ per year (Brigada Militar de Caraá, 2012); in the weather station close to F2, in the city of Campo Bom (29⒋ 'S; 51 $03^{\circ}$ 'W; $25.8 \mathrm{~m}$ alt.), rainfall is about $1,500 \mathrm{~mm}$ per year. 


\subsection{Sampling}

In both fragments, at least 40 phorophytes of arboreal angiosperms, measuring at least $10 \mathrm{~cm}$ in diameter at breast height $(\mathrm{CBH})$ were selected for the study of the epiphytic community using the centered quadrant method (Cottam and Curtis, 1956). Sampling points were defined at $20 \mathrm{~m}$ intervals along a $200 \mathrm{~m}$ transect. The trees were divided according to Braun-Blanquet (1979) into four ecological zones: (1) lower bole, (2) upper bole or transition from upper bole to internal crown, (3) internal crown, and (4) external crown.

\subsection{Floristic inventory}

The floristic inventory was made during bimonthly visits in 2010 and 2011 by means of direct observation of the plants in the epiphytic environment or by using a combination of phorophyte climbing and observation from a distance with binoculars (BUSHNELL ${ }^{\circledR}$ - 96m AT 1000M). Representative fertile specimens were collected, labelled and classified according to the technique described by Guedes-Bruni et al. (2002). Species were identified according to the taxonomic literature, comparisons with botanical collections in herbaria, or consultations with specialists. Angiosperms were classified according to the APG III system (APG, 2009), and the ferns, according to Smith et al. (2006; 2008). Voucher material was deposited in the Herbarium Anchieta (PACA) in São Leopoldo, Brazil. Species were classified according to the type of association with phorophytes in the ecological categories described by Benzing (1995): holoepiphytes do not have any relation with the ground, as they complete all their life cycle in the epiphytic environment, and may be habitual, accidental or facultative; hemiepiphytes have a relationship with the ground, which may be primary, when their growth begins in the phorophyte, or secondary, when their growth begins in the ground. Floristic similarity between the two epiphyte communities was calculated using the Jaccard index based on a matrix of presence and absence of species.

\subsection{Richness}

For both fragments, a rarefaction curve was obtained (Gotelli and Colwell, 2001) to evaluate the association between the increase of specific richness and the number of phorophyte samples, at $95 \%$ confidence intervals and using the EstimateS 7.5 software. The curve stabilisation was considered an asymptote. The number of species for the total sample was estimated with the same software and 50 random repeated sampling with the Jackknife 1 nonparametric estimator, which uses data about species presence or absence.

The normal distribution of data about richness was evaluated using the Shapiro-Wilk test using the SPSS 20.0 program. Differences between the richness of the zones in each fragment were evaluated using the Kruskal-Wallis test followed by the Student-Newman-Keuls test, at $5 \%$ probability. Mean richness values between fragments were compared using the Mann-Whitney test, and the level of significance was set at $5 \%$.

\subsection{Phytosociological parameters}

Absolute and relative frequencies of species per phorophyte and zone were calculated using the method described by Waechter (1998). For each species, a cover score was assigned to the corresponding zone according to the scale described by Kersten and Kunyioshi (2006): (1) very small and isolated individuals; (3) few small individuals or one larger individual; (5) medium-sized individuals or many small individuals; (7) large individuals or many medium-sized individuals; and (10) very large individuals or many large individuals. The sum of cover scores per zone was used to calculate relative cover for each species. The importance value was the mean of the sum of relative frequencies in the phorophytes and in the zones, and of the relative cover. Specific diversity was determined by the Shannon index (H'), using the natural logarithm of frequency data; equability was determined according to the Pielou index (J') (Magurran, 1988).

\section{Results}

\subsection{Floristic inventory}

In F1, there were 30 species distributed into 15 genera and four families, and in F2, 25 species in 19 genera and eight families (Table 1). The three richest families in both fragments were Polypodiaceae, Orchidaceae and Bromeliaceae. Aspleniaceae, Blechnaceae and Pteridaceae had only one species each. Besides Pleopeltis Humb. \& Bonpl. ex Willd. in F1, Tillandsia L. was the richest genus in both fragments. A total of eight genera had only one species. The analysis of ecological category revealed that habitual holoepiphytes were predominant, with $97.56 \%$ (39 species) of the total number of species. Asplenium claussenii and Blechnum binervatum were the only species classified as accidental holoepiphytes and secondary hemiepiphytes, both found only in F2. Of all the species found in the two fragments, 15 were common to both fragments, 15 were exclusive of F1, and 10, of F2. The similarity between F1 and F2 was low, and the Jaccard index was 0.38 .

\subsection{Richness}

The rarefaction curve based on the number of sampling units in both areas was not an asymptote (Figure 1). The richness estimator (Jackknife 1) showed that there might be even more species, and that 32.9 were estimated for F1 and 29.9 for F2. Mean total richness in F1 was $6.5 \pm 2.7$ species per tree, and a minimum of two and maximum of 13 species per phorophyte were recorded. In F2, mean total richness was $6.0 \pm 2.1$ species per tree, and a minimum of three and maximum of 11 species per phorophyte were recorded. Statistical analyses showed that means were not significantly different $(\mathrm{U}=710.00$; $P=0.386$ ). In F1, phorophyte zone 2 had the highest mean richness without, however, being significantly different from zone 1. The highest richness means in F2 were recorded in the intermediate phorophyte zones (2 and 3). The comparison of the two areas revealed that mean richness recorded in zone 1 of the trees in F1 was 
Table 1. Families and species of vascular epiphytes recorded in fragments 1 and 2, located in the upper and lower sections of the Sinos River basin. (HAB - habitual holoepiphyte; SHE = secondary hemiepiphyte; ACC = accidental holoepiphyte).

\section{Family/species}

ASPLENIACEAE

Asplenium claussenii Hieron.

BLECHNACEAE

Blechnum binervatum (Poir.) C.V. Morton \& Lellinger BROMELIACEAE

Aechmea calyculata (E. Morren) Baker

Billbergia nutans H.H. Wendl. ex Regel

Tillandsia aeranthos (Loisel.) L.B. Sm.

Tillandsia gardneri Lindl.

Tillandsia geminiflora Brongn.

Tillandsia recurvata $(\mathrm{L}.) \mathrm{L}$.

Tillandsia tenuifolia $\mathrm{L}$.

Vriesea $\mathrm{sp.}$

Vriesea gigantea Gaudich.

Vriesea rodigasiana $\mathrm{E}$. Morren

Vriesea vagans (L.B. Sm.) L.B. Sm.

CACTACEAE

Lepismium cruciforme (Vell.) Miq.

Rhipsalis teres (Vell.) Steud.

ORCHIDACEAE

Acianthera hygrophila (Barb. Rodr.) Pridgeon \& M.W. Chase

Acianthera saurocephala (Lodd.) Pridgeon \& M.W. Chase

Acianthera sonderana (Rchb. f.) Pridgeon \& M.W. Chase

Baptistonia cornigera (Lindl.) Chiron \& V.P.Castro

Brasiliorchis sp.

Campylocentrum aromaticum Barb. Rodr.

Cattleya intermedia Grah.

Coppensia flexuosa (Sims) Campacci

Isochilus linearis (Jacq.) R. Br.

Lophiaris pumila (Lindl.) Braem

Pabstiella mirabilis (Schltr.) Brieger \& Senghas

Polystachya estrellensis Rchb. f.

PIPERACEAE

Peperomia sp.

Peperomia tetraphylla (G. Forst.) Hook. \& Arn.

PTERIDACEAE

Vittaria lineata $(\mathrm{L}$.) $\mathrm{Sm}$.

POLYPODIACEAE

Campyloneurum austrobrasilianum (Alston) de la Sota

Campyloneurum nitidum (Kaulf.) C. Pres1

Microgramma squamulosa (Kaulf.) de la Sota

Microgramma vacciniifolia (Langsd. \& Fisch.) Copel.

Pecluma recurvata (Kaulf.) M.G. Price

Pleopeltis astrolepis (Liebm.) E. Fourn.

Pleopeltis hirsutissima (Raddi) de la Sota

Pleopeltis pleopeltidis (Fée) de la Sota

Pleopeltis pleopeltifolia (Raddi) Alston

Pleopeltis polypodioides (L.) Andrews \& Windham
Ecological category

\begin{tabular}{|c|c|c|}
\hline & $X$ & $\mathrm{ACC}$ \\
\hline & $\mathrm{X}$ & SHE \\
\hline & $X$ & HAB \\
\hline & $\mathrm{X}$ & HAB \\
\hline$X$ & $X$ & HAB \\
\hline$X$ & & HAB \\
\hline$X$ & $X$ & HAB \\
\hline$X$ & $X$ & HAB \\
\hline$X$ & & HAB \\
\hline$X$ & $X$ & HAB \\
\hline$X$ & & HAB \\
\hline & $X$ & HAB \\
\hline$X$ & & HAB \\
\hline & $X$ & HAB \\
\hline & $X$ & HAB \\
\hline & & HAB \\
\hline$X$ & & HAB \\
\hline$X$ & & HAB \\
\hline$X$ & & HAB \\
\hline$X$ & & HAB \\
\hline$X$ & & HAB \\
\hline & $X$ & HAB \\
\hline$X$ & & HAB \\
\hline$X$ & $X$ & HAB \\
\hline$X$ & & HAB \\
\hline$X$ & $\mathrm{X}$ & HAB \\
\hline$X$ & $X$ & HAB \\
\hline$X$ & $X$ & HAB \\
\hline & $X$ & HAB \\
\hline$X$ & $X$ & HAB \\
\hline & $X$ & HAB \\
\hline$X$ & & HAB \\
\hline$X$ & $X$ & HAB \\
\hline$X$ & $X$ & HAB \\
\hline$X$ & $X$ & HAB \\
\hline$X$ & & HAB \\
\hline$X$ & & HAB \\
\hline$X$ & X & HAB \\
\hline$X$ & $\mathrm{X}$ & HAB \\
\hline$X$ & $X$ & HAB \\
\hline$X$ & & HAB \\
\hline
\end{tabular}


higher than in the same zone of the phorophytes in F2, and the opposite was found in zones 3 and 4. In F1 and F2, zone 2 had statistically equivalent mean values of epiphytic species (Table 2).

\subsection{Phytosociological parameters}

Microgramma squamulosa had the highest importance value (IV) in both fragments and accounted for $87.5 \%$ of the phorophytes in F1 and $80.0 \%$ in F2. In F1, the second most important species was Pleopeltis pleopeltifolia (11.65\%), and in F2, Campyloneurum nitidum (15.74\%), which accounted for $62.5 \%$ and $82.5 \%$ of the phorophytes, respectively (Tables 3 and 4). In F1, Microgramma vacciniifolia,
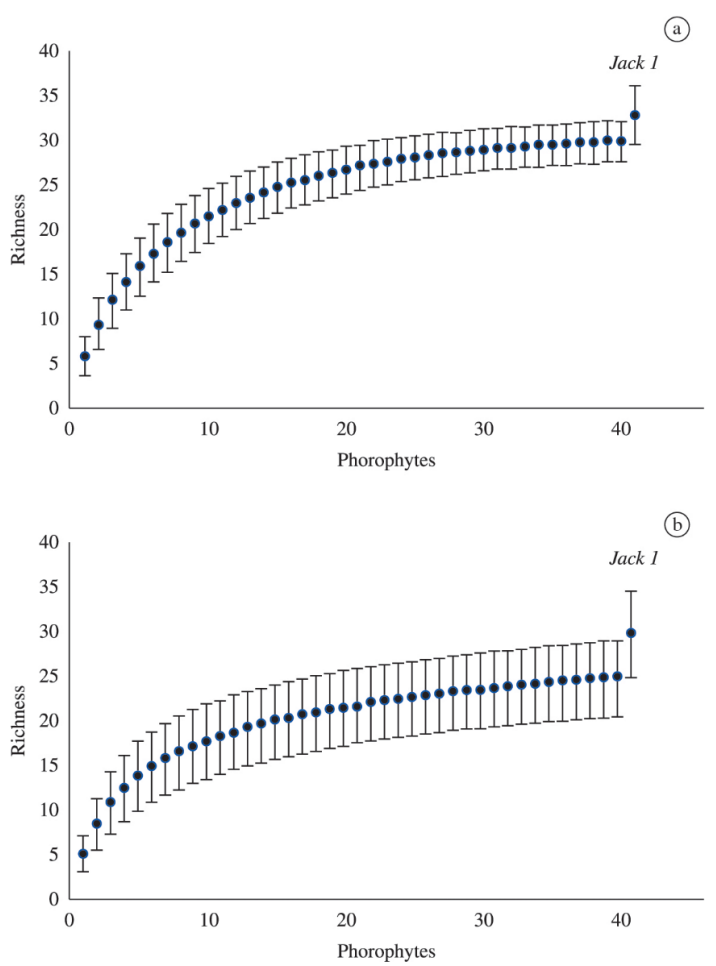

Figure 1. Rarefaction curves and vascular epiphytic richness estimate (Jackknife 1) in fragments of the Atlantic Forest in the (a) upper (F1) and (b) lower (F2) sections of the Sinos River basin, in the state of Rio Grande do Sul, Brazil. Bars indicate confidence interval.
Cattleya intermedia and Lophiaris pumila were recorded in only one phorophyte and had, consequently, the lowest importance value (Table 3). In F2, Billbergia nutans, Vriesea rodigasiana, Blechnum binervatum and Pleopeltis hirsutissima were also found in only one phorophyte and had the lowest importance value (Table 4). The Shannon diversity indices ( $\left.\mathrm{H}^{\prime}\right)$ estimated for F1 and F2 were 2.72 and 2.55 , and the equability indices $(\mathrm{J})$ were 0.80 and 0.79 .

\section{Discussion}

The area where the dense ombrophilous forest (F1) was predominant had a higher specific richness than the semi-deciduous seasonal forest (F2). The lower epiphytic richness of seasonal forests when compared with ombrophilous forests has already been described by other authors in the southern region of Brazil (Aguiar et al., 1981; Waechter, 1998; Borgo et al., 2002; Borgo and Silva, 2003). The specific richness in $\mathrm{F} 1$ was lower than that found by Blum et al. (2011) who recorded 278 species in 6.3 ha of ombrophilous forest which characterize a primary forest with little disturbance (Blum, 2006). The specific richness in F2 was greater than that found in other studies also conducted in the semi-deciduous seasonal forest. Aguiar et al. (1981) recorded 19 species in 37 phorophytes; Dettke et al. (2008), 22 species in 90 phorophytes; and Bataghin et al. (2010), 21 species in 270 phorophytes. Only Borgo et al. (2002) recorded a richer epiphytic flora (32 species), but based on the observation of 2,895 trees.

The families with the highest number of species in this study (Orchidaceae, Bromeliaceae and Polypodiaceae) are also the richest worldwide (Madison, 1977; Kress, 1986; Benzing, 1990), in neotropical regions (Gentry and Dodson, 1987) and in Brazil (Kersten, 2010). Other inventories of vascular epiphytes conducted in the Brazilian states of Rio Grande do Sul (Waechter, 1986, 1998; Gonçalves and Waechter, 2003; Rogalski and Zanin, 2003; Buzatto et al., 2008; Staudt et al., 2012) and of Paraná (Kersten and Silva, 2001; Borgo and Silva, 2003; Hefler and Faustioni, 2004; Dettke et al., 2008; Kersten et al., 2009; Bonnet et al., 2010; 2011; Blum et al., 2011) showed that these families have a great specific richness.

There was a concentration of vascular epiphyte species in few families, as found by Madison (1977), Kress (1986), Gentry and Dodson (1987) and Kersten (2010). According to

Table 2. Mean vascular epiphytic richness in the different phorophyte zones in a fragment of the Atlantic Forest of the upper (F1) and lower (F2) sections of the Sinos River basin, in the state of Rio Grande do Sul, Brazil.

\begin{tabular}{|c|c|c|c|c|c|c|}
\hline Fragment & $\begin{array}{c}\text { Zone } 1 \\
(\text { mean } \pm \text { SD) }\end{array}$ & $\begin{array}{c}\text { Zone } 2 \\
(\text { mean } \pm \text { SD })\end{array}$ & $\begin{array}{c}\text { Zone } 3 \\
(\text { mean } \pm \text { SD })\end{array}$ & $\begin{array}{c}\text { Zone } 4 \\
(\text { mean } \pm \text { SD })\end{array}$ & $\mathbf{H}$ & $P$ \\
\hline F1 & $2.30 \pm 1.67 \mathrm{ab} \mathrm{A}$ & $3.40 \pm 2.11 \mathrm{a} \mathrm{A}$ & $1.92 \pm 1.79 \mathrm{~b} \mathrm{~B}$ & $0.45 \pm 1.26 \mathrm{c} \mathrm{B}$ & 51.7174 & $<0.001$ \\
\hline $\mathrm{F} 2$ & $1.17 \pm 1.03 \mathrm{~b} \mathrm{~B}$ & $2.90 \pm 1.97 \mathrm{a} \mathrm{A}$ & $2.85 \pm 1.39 \mathrm{a} \mathrm{A}$ & $1.97 \pm 1.92 \mathrm{~b} \mathrm{~A}$ & 32.8759 & $<0.001$ \\
\hline $\mathrm{U}$ & 482.00 & 705.50 & 496.00 & 315.50 & & \\
\hline$P$ & 0.002 & 0.363 & 0.003 & $<0.001$ & & \\
\hline
\end{tabular}

$\mathrm{H}=$ Kruskal-Wallis test; $\mathrm{U}=$ Mann-Whitney test $P=$ probability; $\mathrm{SD}=$ standard deviation. Means with different lower case letters in the same line are significantly different by the Student-Newman-Keuls test at $5 \%$ probability. Means with different upper case letters in the same column are significantly different by the Mann-Whitney test at 5\% probability. 
Table 3. Community structure of vascular epiphytes in fragment 1 in decreasing order of importance value (IV). (np=number of phorophytes with species; $\mathrm{nz}=$ number of zones with species; AFf = absolute frequency of species on phorophytes; $\mathrm{RFf}=$ relative frequency of species on phorophytes; $\mathrm{AFz}=$ absolute frequency of species on zones; $\mathrm{RFz}=$ relative frequency of species on zones; $\mathrm{ADo}=$ absolute dominance of species (sum of coverage grades); RDo = relative dominance of species).

\begin{tabular}{|c|c|c|c|c|c|c|c|c|c|}
\hline Species & np & nz & AFf & RFf & $\mathbf{A F z}$ & $\mathbf{R F z}$ & ADo & RDo & IV \\
\hline Microgramma squamulosa & 35 & 58 & 87.5 & 14.58 & 36.25 & 16.76 & 195 & 24.59 & 18.65 \\
\hline Pleopeltis pleopeltifolia & 25 & 43 & 62.5 & 10.42 & 26.87 & 12.43 & 96 & 12.11 & 11.65 \\
\hline Pleopeltis pleopeltidis & 28 & 36 & 70 & 11.67 & 22.5 & 10.40 & 76 & 9.58 & 10.55 \\
\hline Vriesea gigantea & 11 & 22 & 27.5 & 4.58 & 13.75 & 6.36 & 86 & 10.84 & 7.26 \\
\hline Tillandsia aeranthos & 14 & 24 & 35 & 5.83 & 15 & 6.94 & 50 & 6.31 & 6.36 \\
\hline Tillandsia gardneri & 15 & 21 & 37.5 & 6.25 & 13.12 & 6.07 & 37 & 4.67 & 5.66 \\
\hline Tillandsia geminiflora & 11 & 14 & 27.5 & 4.58 & 8.75 & 4.05 & 21 & 2.65 & 3.76 \\
\hline Campyloneurum nitidum & 12 & 13 & 30 & 5.00 & 8.12 & 3.76 & 19 & 2.40 & 3.72 \\
\hline C. austrobrasilianum & 10 & 14 & 25 & 4.17 & 8.75 & 4.05 & 14 & 1.77 & 3.33 \\
\hline Polystachya estrellensis & 10 & 12 & 25 & 4.17 & 7.5 & 3.47 & 16 & 2.02 & 3.22 \\
\hline Pleopeltis hirsutissima & 9 & 10 & 22.5 & 3.75 & 6.25 & 2.89 & 18 & 2.27 & 2.97 \\
\hline Coppensia flexuosa & 5 & 8 & 12.5 & 2.08 & 5 & 2.31 & 16 & 2.02 & 2.14 \\
\hline Tillandsia tenuifolia & 4 & 6 & 10 & 1.67 & 3.75 & 1.73 & 18 & 2.27 & 1.89 \\
\hline Isochilus linearis & 4 & 6 & 10 & 1.67 & 3.75 & 1.73 & 18 & 2.27 & 1.89 \\
\hline Tillandsia recurvata & 5 & 7 & 12.5 & 2.08 & 4.37 & 2.02 & 11 & 1.39 & 1.83 \\
\hline Baptistonia cornigera & 5 & 5 & 12.5 & 2.08 & 3.12 & 1.45 & 11 & 1.39 & 1.64 \\
\hline Acianthera saurocephala & 3 & 8 & 7.5 & 1.25 & 5 & 2.31 & 8 & 1.01 & 1.52 \\
\hline Peperomia tetraphylla & 5 & 5 & 12.5 & 2.08 & 3.12 & 1.45 & 7 & 0.88 & 1.47 \\
\hline Acianthera sonderana & 4 & 4 & 10 & 1.67 & 2.5 & 1.16 & 8 & 1.01 & 1.28 \\
\hline Pleopeltis astrolepis & 4 & 4 & 10 & 1.67 & 2.5 & 1.16 & 8 & 1.01 & 1.28 \\
\hline Pleopeltis polypodioides & 3 & 4 & 7.5 & 1.25 & 2.5 & 1.16 & 8 & 1.01 & 1.14 \\
\hline Vriesea $\mathrm{sp}$. & 3 & 3 & 7.5 & 1.25 & 1.87 & 0.87 & 9 & 1.13 & 1.08 \\
\hline Vriesea vagans & 3 & 3 & 7.5 & 1.25 & 1.87 & 0.87 & 9 & 1.13 & 1.08 \\
\hline Acianthera hygrophila & 2 & 3 & 5 & 0.83 & 1.87 & 0.87 & 11 & 1.39 & 1.03 \\
\hline Pabstiella mirabilis & 3 & 4 & 7.5 & 1.25 & 2.5 & 1.16 & 4 & 0.50 & 0.97 \\
\hline Brasiliorchis sp. & 2 & 3 & 5 & 0.83 & 1.87 & 0.87 & 7 & 0.88 & 0.86 \\
\hline Pecluma recurvata & 2 & 2 & 5 & 0.83 & 1.25 & 0.58 & 2 & 0.25 & 0.55 \\
\hline Microgramma vacciniifolia & 1 & 2 & 2.5 & 0.42 & 1.25 & 0.58 & 4 & 0.50 & 0.50 \\
\hline Cattleya intermedia & 1 & 1 & 2.5 & 0.42 & 0.625 & 0.29 & 3 & 0.38 & 0.36 \\
\hline Lophiaris pumila & 1 & 1 & 2.5 & 0.42 & 0.625 & 0.29 & 3 & 0.38 & 0.36 \\
\hline
\end{tabular}

Gentry and Dodson (1987), a small number of families may also reflect the specialization of some of these families in the environments under study. This trend in the distribution of species was also found in other inventories of epiphytic communities conducted in southern and southeastern Brazil (Waechter, 1986; 1992; 1998; Kersten and Silva, 2001, Borgo et al., 2002; Borgo and Silva, 2003; Gonçalves and Waechter, 2003; Rogalski and Zanin, 2003; Hefler and Faustioni, 2004; Buzatto et al., 2008; Dettke et al., 2008; Menini-Neto et al., 2009; Mania and Monteiro, 2010; Staudt et al., 2012). The three richest families accounted for $82.5 \%$ of the recorded species. According to Kersten (2010), $91 \%$ of the species in Brazil are part of the 10 richest families, and in the case of the 20 richest families, this percentage may reach $98 \%$ of the total species recorded. The success of these three families in the epiphytic environment is associated with several adaptations to drought resistance and water saving (Staudt et al., 2012).
The predominance of habitual holoepiphytes over the other categories has also been observed by Aguiar et al. (1981), Waechter (1986; 1998); Kersten and Silva (2001; 2002); Borgo et al. (2002); Borgo and Silva (2003); Gonçalves and Waechter (2003); Rogalski and Zanin (2003), Giongo and Waechter (2004); Kersten and Kunyioshi (2006) and Schmitt and Windisch (2010). Habitual holoepiphytes had more specialized and diversified vegetative adaptations, which favoured a more generalized distribution of forest formations (Fraga et al., 2008).

The inventory of all species in an area is virtually impossible (Santos, 2004). The richness estimator indicated that $91 \%$ and $83 \%$ of the total richness was sampled in F1 and F2. These estimates are not precise previews of the actual number of species, but they indicate minimum expected values (Colwell et al., 2004) in the epiphytic communities in both fragments.

Microgramma squamulosa (Polypodiaceae) had the highest importance value in both fragments, in the same way 
Table 4. Community structure of vascular epiphytes in fragment 2 in decreasing order of importance value (IV). (np=number of phorophytes with species; $\mathrm{nz}=$ number of zones with species; $\mathrm{AFf}=$ absolute frequency of species on phorophytes; RFf $=$ relative frequency of species on phorophytes; $\mathrm{AFz}=$ absolute frequency of species on zones; $\mathrm{RFz}=$ relative frequency of species on zones; Ado = absolute dominance of species (sum of coverage grades); RDo = relative dominance of species).

\begin{tabular}{|c|c|c|c|c|c|c|c|c|c|}
\hline Species & np & $\mathbf{n z}$ & AFf & RFf & $\mathrm{AFz}$ & $\mathbf{R F z}$ & ADo & RDo & IV \\
\hline Microgramma squamulosa & 32 & 61 & 80.0 & 13.62 & 38.13 & 17.43 & 211 & 21.21 & 17.42 \\
\hline Campyloneurum nitidum & 33 & 63 & 82.5 & 14.04 & 39.38 & 18.00 & 151 & 15.18 & 15.74 \\
\hline Peperomia sp. & 19 & 35 & 47.5 & 8.09 & 21.88 & 10.00 & 123 & 12.36 & 10.15 \\
\hline Rhipsalis teres & 21 & 27 & 52.5 & 8.94 & 16.88 & 7.71 & 107 & 10.75 & 9.13 \\
\hline Pleopeltis pleopeltifolia & 16 & 22 & 40.0 & 6.81 & 13.75 & 6.29 & 70 & 7.04 & 6.71 \\
\hline Coppensia flexuosa & 14 & 18 & 35.0 & 5.96 & 11.25 & 5.14 & 58 & 5.83 & 5.64 \\
\hline Tillandsia aeranthos & 14 & 18 & 35.0 & 5.96 & 11.25 & 5.14 & 34 & 3.42 & 4.84 \\
\hline Tillandsia geminiflora & 12 & 16 & 30.0 & 5.11 & 10.00 & 4.57 & 43 & 4.32 & 4.67 \\
\hline Peperomia tetraphylla & 15 & 17 & 37.5 & 6.38 & 10.63 & 4.86 & 22 & 2.21 & 4.48 \\
\hline Pleopeltis pleopeltidis & 8 & 12 & 20.0 & 3.40 & 7.50 & 3.43 & 30 & 3.02 & 3.28 \\
\hline Pabstiella mirabilis & 10 & 11 & 25.0 & 4.26 & 6.88 & 3.14 & 13 & 1.31 & 2.90 \\
\hline Vriesea sp. & 5 & 6 & 12.5 & 2.13 & 3.75 & 1.71 & 22 & 2.21 & 2.02 \\
\hline Microgramma vacciniifolia & 4 & 7 & 10.0 & 1.70 & 4.38 & 2.00 & 21 & 2.11 & 1.94 \\
\hline Campylocentrum aromaticum & 5 & 6 & 12.5 & 2.13 & 3.75 & 1.71 & 16 & 1.61 & 1.82 \\
\hline Polystachya estrellensis & 4 & 6 & 10.0 & 1.70 & 3.75 & 1.71 & 17 & 1.71 & 1.71 \\
\hline Aechmea calyculata & 3 & 4 & 7.5 & 1.28 & 2.50 & 1.14 & 13 & 1.31 & 1.24 \\
\hline Vittaria lineata & 4 & 5 & 10.0 & 1.70 & 3.13 & 1.43 & 5 & 0.50 & 1.21 \\
\hline Tillandsia recurvata & 4 & 4 & 10.0 & 1.70 & 2.50 & 1.14 & 7 & 0.70 & 1.18 \\
\hline Oncidium pumilum & 4 & 4 & 10.0 & 1.70 & 2.50 & 1.14 & 4 & 0.40 & 1.08 \\
\hline Lepismium cruciforme & 2 & 2 & 5.0 & 0.85 & 1.25 & 0.57 & 8 & 0.80 & 0.74 \\
\hline Asplenium claussenii & 2 & 2 & 5.0 & 0.85 & 1.25 & 0.57 & 4 & 0.40 & 0.61 \\
\hline Billbergia nutans & 1 & 1 & 2.5 & 0.43 & 0.63 & 0.29 & 7 & 0.70 & 0.47 \\
\hline Vriesea rodigasiana & 1 & 1 & 2.5 & 0.43 & 0.63 & 0.29 & 3 & 0.30 & 0.34 \\
\hline Blechnum binervatum & 1 & 1 & 2.5 & 0.43 & 0.63 & 0.29 & 3 & 0.30 & 0.34 \\
\hline Pleopeltis hirsutissima & 1 & 1 & 2.5 & 0.43 & 0.63 & 0.29 & 3 & 0.30 & 0.34 \\
\hline
\end{tabular}

as found in studies conducted by Kersten and Silva (2001), Kersten and Kuniyoshi (2009) and Geraldino et al. (2010). This species has been described as a pioneer (Kersten and Silva, 2001; Geraldino et al., 2010), which confirms the secondary character of the fragments under analysis. Microgramma squamulosa is found in not very dense primary and secondary forests, over isolated trees, even in parks, as well as on stone walls (Sehnem, 1970), which confirms its high plasticity and adaptation to different environments. It extends over boles and branches and takes up large areas, which is the reason why it has small individuals and reptant growth.

The species with the second highest importance value in F1, Pleopeltis pleopeltifolia (Polypodiaceae), was also the second in the mixed ombrophilous forest (Kersten and Kuniyoshi, 2009) in the state of Paraná, as well as in the ecotone between the semi-deciduous seasonal and the mixed ombrophilous forests (Geraldino et al., 2010) in the same state. In the same way as in F2, Campyloneurum nitidum (Polypodiaceae) had the second highest importance value in the inventory conducted by Schneider and Schmitt (2011) in a semi-deciduous seasonal forest in the state of Rio Grande do Sul, but they considered only phorophytes of Alsophila setosa Kaulf.
In these three Polypodiaceae species, adaptations such as frond trichomes (Müller et al., 1981), rhizome succulence (Waechter, 1992), poikilohydry (Benzing, 1990) and the higher sclerophylly index and stomatal density prevent dehydration (Rocha et al., 2013) and facilitate a greater occupation of phorophytes, increasing their importance in the organisation of the epiphytic community.

Diversity indices found in F1 and F2 were very similar, and mean total richness recorded in phorophytes was statistically equivalent. The values of the Shannon index in the fragments were close to those recorded by Waechter (1998) in Emboaba, in the city of Osório (2.99), and by Waechter (1992) in Taim, in the city of Rio Grande (2.89), in the coastal plains of Rio Grande do Sul, as well as by Kersten and Silva (2002) in a mixed ombrophilous forest (2.71) in the state of Paraná, Brazil. They were lower than the values found by Giongo and Waechter (2004) in riparian forests in Rio Grande do Sul (3.43), Kersten and Silva (2001) in Ilha do Mel (3.61), Kersten and Kunyioshi (2006) in a dense ombrophilous forest (4.07) and Geraldino et al. (2010) in a transition area between a mixed ombrophilous forest and a semi-deciduous seasonal forest (3.17) in the state of Paraná. The lower values found in this study, particularly in relation to other 
places in Paraná, reflect their geographic location, which was characteristically more subtropical in the areas under analysis. The high diversity and the richness of vascular epiphytes in the tropical regions visually decrease towards the south because of the lower temperatures and greater rainfall, as well as the variations in environmental conditions due to the topography (Waechter, 1992).

The trend towards an increase in mean richness from zone 1 to zone 2 in both fragments is associated with the fact that boles are areas that do not usually promote epiphyte colonisation because of their verticality (Bøgh, 1992), less luminosity (Parker, 1995) and exposure to the action of herbivorous animals (bovine cattle) that move around the trees (Gonçalves and Waechter, 2002), as well as to the extraction of ornamental epiphytic plants. Human action may be one of the determinant factors of differences in richness found in zone 1 in F1 when compared with F2. In F2, an urban park used for leisure, public visitation is intense, and epiphytes with any ornamental value may have been removed illegally from the tree boles. Epiphytes are usually more diversified in intermediate zones, where phorophyte structures provide the necessary space and support for epiphytic flora (Nieder et al., 1999), as seen in both areas under analysis, but more evident in F2. The decrease in mean richness in both fragments from zone 3 to zone 4 is associated with the fact that the latter is the most recent part of the tree and, consequently, it had the shortest time to receive epiphytes. Yeaton and Gladstone (1982) reported that substrate availability time is an important factor in the development of epiphytic plants in phorophytes. The external crown branches are thinner with smaller areas and less diversified structurally, which may result in a smaller number of species. In addition, in the external crown there is great microclimate variability characterised by long periods of low humidity, high temperatures and strong winds (Krömer et al., 2007).

Although both F1 and F2 belong to the Atlantic Forest Biome and had similar richness means and diversity indices, there were exclusive species in each area, which resulted in low similarity and revealed a characteristic floristic identity in each area. This low coefficient of similarity between epiphytic floras of the two study areas was expected due to environmental differences such as altitude and forest type. Regardless of the nature of the matrix, whether urban or rural, in which the fragments are located, all should be taken into consideration when defining handling and preservation procedures. Therefore, if more fragments are protected, a larger number of epiphytic species may be preserved in the Sinos River basin.

\section{Acknowledgements}

The authors wish to thank: the Universidade Feevale for the use of the laboratory and financial support; the Coordenação de Aperfeiçoamento de Pessoal de Nivel Superior (CAPES) for the Master's grant awarded to M.D. Barbosa; the Fundação de Amparo à Pesquisa no Rio Grande do Sul (FAPERGS) for the scholarship awarded to S. Cunha; the land owner and the Henrique Luís Roessler park staff for research permission and logistic assistance.

\section{References}

AGUIAR, LW., CITADINI-ZANETTE, V., MARTAU, L. and BACKES, A., 1981. Composição florística de epífitos vasculares numa área localizada nos municípios de Montenegro e Triunfo, Rio Grande do Sul, Brasil. Iheringia Série Botânica, vol. 28, no. 1 , p. 55-93.

BARTHLOTT, W., SCHMIT-NEUERBURG, V., NIEDER, J. and ENGWALD, S., 2001. Diversity and abundance of vascular epiphytes: a composition of secondary vegetation and primary montane rain forest in the Venezuelan Andes. Plant Ecology, vol. 152, no. 2, p. 145-156. http://dx.doi.org/10.1023/A:1011483901452.

BATAGHIN, FA., BARROS, F. and PIRES, JSR., 2010. Distribuição da comunidade de epífitos vasculares em sítios sob diferentes graus de perturbação na Floresta Nacional do Ipanema, São Paulo, Brasil. Revista Brasileira de Botânica. Brazilian Journal of Botany, vol. 33, no. 3, p. 501-512. http://dx.doi.org/10.1590/ S0100-84042010000300012.

BECKER, DFP., CUNHA, S., MARCHIORETTO, MS. and SCHMITT, JL., 2013. Riqueza, estrutura comunitária e distribuição vertical de epífitos vasculares no Parque Natural Municipal Tupancy, Arroio do Sal, RS, Brasil. Pesquisas, vol. 64, p. 127-139.

BENZING, DH., 1990. Vascular epiphytes. Cambridge: Cambridge University Press. 354 p.

BENZING, DH., 1995. The physical mosaic and plant variety in forest canopies. Selbyana, vol. 16, no. 2, p. 159-168.

BLUM, CT., 2006. A Floresta Ombrófila Densa na Serra da Prata, Parque Nacional Saint-Hilaire/Lange, PR - Caracterização floristica, fitossociológica e ambiental de um gradiente altitudinal. Curitiba: Universidade Federal do Paraná. 195 p. Dissertação de Mestrado em Ciências Florestais.

BLUM, CT., RODERJAN, CV. and GALVÃO, F., 2011. Composição florística e distribuição altitudinal de epífitas vasculares da Floresta Ombrófila Densa na Serra da Prata, Morretes, Paraná, Brasil. Biota Neotropica, vol. 11, no. 4, p. 141-159. http://dx.doi. org/10.1590/S1676-06032011000400015.

BØGH, A., 1992. The composition and distribution of the vascular epiphyte flora of an Ecuadorian montane rain forest. Selbyana, vol. 13 , p. 25-34.

BONNET, A., CURCIO, GR., LAVORANT, OJ. and GALVÃO, F., 2010. Relações de epífitos vasculares com fatores ambientais nas florestas do Rio Tibagi, Paraná, Brasil.Biotemas, vol. 23, no. 3, p. 37-47.

BONNET, A., CURCIO, GR., LAVORANT, OJ. and GALVÃO, F., 2011. Flora epifítica vascular em três unidades vegetacionais do Rio Tibagi, Paraná, Brasil.Rodriguésia, vol. 62, no. 3, p. 491-498.

BONNET, A., LAVORANTI, OJ. and CURCIO, GR., 2009. Epífitos vasculares no Corredor de Biodiversidade Araucária, bacia do rio Iguaçu, Paraná, Brasil. Cadernos da Biodiversidade, vol. 6, p. 49-70.

BORGO, M. and SILVA, SM., 2003. Epífitos vasculares em fragmentos de Floresta Ombrófila Mista, Curitiba, Paraná, Brasil. Revista Brasileira de Botânica. Brazilian Journal of Botany, vol. 26, no. 3, p. 391-401. http://dx.doi.org/10.1590/ S0100-84042003000300012.

BORGO, M., PETEAN, M. and SILVA, SM., 2002. Epífitos vasculares em um remanescente de floresta estacional semidecidual, 
município de Fênix, PR, Brasil. Acta Biologica Leopoldensia, vol. 24 , no. 2, p. 121-130.

Brasil. Conselho Nacional de Meio Ambiente - CONAMA, Ministério do Meio Ambiente - MMA, 2012. Resoluções do CONAMA: Resoluções vigentes publicadas entre setembro de 1984 e janeiro de 2012. Brasília: MMA. 1126 p.

BRAUN-BLANQUET, J., 1979. Fitossociologia: bases para el estudio de las comunidades vegetales. Madrid: Blume. 820 p.

Brigada Militar de Caraá, 2012. Boletim pluviométrico. Caraá: Brigada Militar de Caraá.

BRUSTULIN, J. and SCHMITT, JL., 2008. Composição florística, distribuição vertical e floração de orquídeas epifíticas em três parques municipais do estado do Rio Grande do Sul, Brasil. Pesquisas, vol. 59, p. 143-158.

BUZATTO, C.R., SEVERO, B M.A. and WAECHTER, J.L., 2008. Composição florística e distribuição ecológica de epífitos vasculares na Floresta Nacional de Passo Fundo, Rio Grande do Sul. Iheringia Serie Botânica, vol. 63, no. 2, p. 231-239.

COLWELL, RK., MAO, CX. and CHANG, J., 2004. Interpolatin, extrapolatin, and comparing incidence-based species accumulation curves.Ecology, vol. 85, no. 10, p. 2717-2727. http://dx.doi. org/10.1890/03-0557.

COTTAM, G. and CURTIS, JT., 1956. The use of distance measures in phytosociological sampling. Ecology, vol. 37, no. 3, p. 451-460. http://dx.doi.org/10.2307/1930167.

DETTKE, GA., ORFRINI, AC. and MILANESE-GUTIERRE, MA., 2008. Composição florística e distribuição de epífitas vasculares em um remanescente alterado da Floresta Estacional Semidecidual do Paraná, Brasil. Rodriguésia, vol. 59, no. 4, p. 859-872.

FLORES-PALACIOS, A. and GARCÍA-FRANCO, JG., 2008. Habitat isolation changes the beta diversity of vascular epiphyte community in lower montane forest, Veracruz, Mexico. Biodiversity and Conservation, vol. 17, no. 1, p. 191-207. http://dx.doi. org/10.1007/s10531-007-9239-6.

FRAGA, LL., SILVA, LB. and SCHMITT, JL., 2008. Composição e distribuição vertical de pteridófitas epifíticas sobre Dicksonia sellowiana Hook. (Dicksoniaceae), em Floresta Ombrófila Mista no sul do Brasil. Biota Neotropica, vol. 8, no. 4, p. 123-129. http:// dx.doi.org/10.1590/S1676-06032008000400011.

Fundação SOS Mata Atlântica and Instituto Nacional de Pesquisas Espaciais -INPE, 2011. Atlas dos remanescentes florestais da Mata Atlâtica: periodo 2008-2010. São Paulo: INPE. 122 p.

GENTRY, AH. and DODSON, CH., 1987. Diversity and biogeography of neotropical vascular epiphytes. Annals of the Missouri Botanical Garden, vol. 74, no. 2, p. 205-233. http:// dx.doi.org/10.2307/2399395.

GERALDINO, HCL., CAXAMBÚ, MG. and SOUZA, DC., 2010. Composição florística e estrutura da comunidade de epífitas vasculares em uma área de ecótono em Campo Mourão, PR, Brasil. Acta Botanica Brasilica, vol. 24, no. 2, p. 469-482. http://dx.doi. org/10.1590/S0102-33062010000200018.

GIONGO, C. and WAECHTER, JL., 2004. Composição florística e estrutura comunitária de epífitos vasculares em uma floresta de galeria na Depressão Central do Rio Grande do Sul. Revista Brasileira de Botânica. Brazilian Journal of Botany, vol. 27, no. 3, p. 563-572. http://dx.doi.org/10.1590/S0100-84042004000300015.
GONÇALVES, CN. and WAECHTER, JL., 2002. Epífitos vasculares sobre espécimes de Ficus organensis isolados no norte da planície costeira do Rio Grande do Sul: padrões de abundância e distribuição.Acta Botanica Brasilica, vol. 16, no. 4, p. 429-441. http://dx.doi.org/10.1590/S0102-33062002000400006.

GONÇALVES, CN. and WAECHTER, JL., 2003. Aspectos florísticos e ecológicos de epífitos vasculares sobre figueiras isoladas no norte da planície costeira do Rio Grande do Sul. Acta Botanica Brasilica, vol. 17, no. 1, p. 89-100. http://dx.doi. org/10.1590/S0102-33062003000100007.

GOTELLI, NJ. and COLWELL, RK., 2001. Quantifying biodiversity: procedures and pitfalls in the measurement and comparison of species richness.Ecology Letters, vol. 4, no. 4, p. 379-391. http:// dx.doi.org/10.1046/j.1461-0248.2001.00230.x.

GUEDES-BRUNI, RR., MORIM, MPM., LIMA, HC. and SYLVESTRE, L., 2002. Inventário florístico. In SYLVESTRE, LS. and ROSA, MMT. (Eds.). Manual metodológico para estudos botânicos na Mata Atlântica. Rio de Janeiro: Universidade Rural. p. 24-49.

HEFLER, SM. and FAUSTIONI, P., 2004. Levantamento florístico de epífitos vasculares do bosque São Cristovão -Curitiba - Paraná - Brasil. Revista Estudos de Biologia, vol. 26, no. 54, p. 11-19.

KERSTEN, RA., 2010. Epífitas vasculares - Histórico, participação taxonômica e aspectos relevantes, com ênfase na Mata Atlântica. Hoehnea, vol. 37, no. 1, p. 9-38. http://dx.doi.org/10.1590/S223689062010000100001.

KERSTEN, RA. and KUNYIOSHI, YS., 2006. Epífitos vasculares na Bacia do Alto Iguaçu, Paraná, Brasil - composição florística. Estudos de Biologia, vol. 28, p. 55-71.

KERSTEN, RA. and KUNIYOSHI, YS., 2009. Conservação das florestas na Bacia do alto Iguaçú, Paraná - Avaliação da comunidade de epífitas vasculares em diferentes estágios serais. Revista Floresta, vol. 39, no. 1, p. 51-66.

KERSTEN, RA., KUNIYIDHI, YS. and RODERJAN, CV., 2009. Epífitas vasculares em duas formações ribeirinhas adjacentes na bacia do rio Iguaçu - Terceiro Planalto Paranaense. Iheringia Série Botânica, vol. 64, no. 1, p. 33-43.

KERSTEN, RA. and SILVA, SM., 2001. Composição florística e estrutura do componente epifítico vascular em floresta da planície litorânea na Ilha do Mel, Paraná, Brasil. Revista Brasileira de Botânica. Brazilian Journal of Botany, vol. 24, no. 2, p. 213-226. http://dx.doi.org/10.1590/S0100-84042001000200012.

KERSTEN, RA. and SILVA, SM., 2002. Florística e estrutura do componente epifítico vascular em Floresta Ombrófila Mista aluvial do Rio Barigüi, Paraná, Brasil. Revista Brasileira de Botânica, São Paulo, vol. 25, no. 3, p. 259-267.

KERSTEN, RA. and SILVA, SM., 2005. Florística e estrutura de comunidades de epífitas vasculares da planície litorânea. In MARQUES, MCM. and BRITEZ, RM. (Eds.). História natural e conservação da Ilha do Mel. Curitiba: Universidade Federal do Paraná. p. 125-144.

KLEIN, RM., 1975. Southern Brazilian phytogeographic features and the probable influence of upper quaternary climatic changes in the floristic distribution. Boletim Paranaense de Geociencias, vol. 33 , p. 67-88.

KRESS, WJ., 1986. The systematic distribution of vascular epiphytes: an update. Selbyana, vol. 9, no. 1, p. 2-22. 
KRÖMER, T., KESSLER, M. and GRADSTEIN, SR., 2007. Vertical stratification of vascular ephytes in submontane and montane Forest of the Bolivian Andes: the importance of the understory. Plant Ecology, vol. 189, no. 2, p. 261-278. http:// dx.doi.org/10.1007/s11258-006-9182-8.

LUGO, AE. and SCATENA, FN., 1992. Epiphytes and climate change research in the Caribbean: a proposal. Selbyana, vol. 13, p. 123-130.

LÜTTGE, U., 1989. Vascular epiphytes: setting the Scene. In LÜTTGE, U. (Ed.). Vascular plants as epiphytes. New York: Springer-Verlag. p. 1-12. Ecological Studies, 79:

MADISON, M., 1977. Vascular epiphytes: their systematic occurrence and salient features. Selbyana, vol. 2, no. 1, p. 1-13.

MAGURRAN, AE., 1988. Ecological diversity and its measurement. Cambridge: British Library.

MANIA, LF. and MONTEIRO, R., 2010. Florística e ecologia de epífitas vasculares em um fragmento de floresta de restinga, Ubatuba, SP, Brasil. Rodriguésia, vol. 61, no. 4, p. 705-713.

MENININETO, L., FORZZA, RC. and ZAPPI, D., 2009. Angiosperm epiphytes as conservation indicators in forest fragments: A case study from southeastern Minas Gerais, Brasil. Biodiversity and Conservation, vol. 18, no. 14, p. 3785-3807. http://dx.doi.org/10.1007/s10531-009-9679-2.

MORENO, JA., 1961. Clima do Rio Grande do Sul.Porto Alegre: Secretaria da Agricultura. 42 p. Secção de Geografia.

MÜLLER, L., STARNECKER, G. and WINKLER, S., 1981. Zur Ökologie epiphytischer Farne in Südbrasilien. I. Saugschuppen. Flora, vol. 171, p. 55-65.

MYERS, N., MITTERMEIER, RA., MITTERMEIER, CG., FONSECA, GA. and KENT, J., 2000. Biodiversity hotspots for conservation priorities. Nature, vol. 403, no. 6772, p. 853-858. http://dx.doi.org/10.1038/35002501. PMid:10706275.

NADKARNI, NM., 1984. Epiphyte biomass and nutrient capital of a neotropical elfin forest. Biotropica, vol. 16, no. 4, p. 249-256. http://dx.doi.org/10.2307/2387932.

NIEDER, J., ENGWALD, S. and BARTHLOTT, W., 1999. Patterns of neotropical epiphyte diversity. Selbyana, vol. 20, no. 1, p. 66-75.

NIEDER, J., IBISCH, PL. and BARTHLOTT, W., 1997. Biodiversidad de epífitas: una cuestión de escala. Revista del Jardín Botánico Nacional, vol. 17/18, p. 59-62.

PARKER, GG., 1995. Structure and microclimate of forest canopies. In LOWMAN, MD. and NADKARNI, NM. (Eds.). Forest canopies. San Diego: Academic Press. p. 73-106.

RAMBO, B., 1954. História da flora do litoral rio-grandense. Sellowia, vol. 6, no. 6, p. 113-172.

ROCHA, CFD., COGLIATTI-CARVALHO, L., NUNES-FREITAS, AF., ROCHA-PESSOA, TC., DIAS, AS., ARIANI, CV. and MORGADO, LN., 2004. Conservando uma larga proporção da diversidade biológica através da conservação de Bromeliaceae. Vidalia, vol. 2, no. 1, p. 52-68.

ROCHA, LD., DROSTE, A., GEHLEN, G. and SCHMITT, JL., 2013. Leaf dimorphism of Microgramma squamulosa (Polypodiaceae): a qualitative and quantitative analysis focusing on adaptations to epiphytism. Revista de Biología Tropical, vol. 61, no. 1, p. 291-299. PMid:23894982.
RODERJAN, CV., GALVÃO, F., KUNIYOSHI, YS. and HATSCHBACH, GG., 2002. As unidades fitogeográficas do estado do Paraná. Ciência e Ambiente, vol. 24, no. 1, p. 75-92.

ROGALSKI, JM. and ZANIN, EM., 2003. Composição florística de epífitos vasculares no estreito de Augusto César, Floresta Estacional Decidual do Rio Uruguai, RS, Brasil. Revista Brasileira de Botânica. Brazilian Journal of Botany, vol. 26, no. 4, p. 551556. http://dx.doi.org/10.1590/S0100-84042003000400014.

ROSA, NA., 2010. Plano de Manejo - Parque Municipal Henrique Luís Roessler-Parcão. Novo Hamburgo: Prefeitura Municipal de Novo Hamburgo. 846 p.

SANTOS, AJ., 2004. Estimativas de riqueza em espécies. In CULLEN-JÚNIOR, L., VALLADARES-PADUA, C. and RUDY, R. (Eds.). Métodos de estudos em biologia da conservação e manejo da vida silvestre. Curitiba: UFPR. p. 19-41.

SCHMITT, JL. and WINDISCH, PG., 2005. Aspectos ecológicos de Alsophila setosa Kaulf. (Cyatheaceae, Pteridophyta) no Rio Grande do Sul, Brasil. Acta Botanica Brasilica, vol. 19, no. 4, p. 861-867. http://dx.doi.org/10.1590/S0102-33062005000400021.

SCHMITT, JL. and WINDISCH, PG., 2010. Biodiversity and spatial distribution of epiphytic ferns on Alsophila setosa Kaulf. (Cyatheaceae) caudices in Rio Grande do Sul, Brazil. Brazilian Journal of Biology $=$ Revista Brasleira de Biologia, vol. 70, no. 3, p. 521-528. http://dx.doi.org/10.1590/S1519-69842010000300008. PMid:20730338.

SCHMITT, JL., BUDKE, JC. and WINDISCH, PG., 2005. Aspecto florísticos e ecológicos de pteridófitas epifíticas em cáudices de Dicksonia sellowiana Hook. (Pteridophyta, Dicksoniaceae), São Francisco de Paula, RS, Brasil. Pesquisas, vol. 56, p. 161-172.

SCHNEIDER, PH. and SCHMITT, JL., 2011. Composition, community structure and vertical distribution of epiphytic ferns on Alsophila setosa Kaulf., in a Semideciduous Seasonal Forest, Morro Reuter, RS, Brasil. Acta Botanica Brasilica, vol. 25, no. 3, p. 557-562. http://dx.doi.org/10.1590/S0102-33062011000300007.

SEHNEM, A.,1970. Polipodiáceas. In REITZ, R. (Ed.). Flora ilustrada catarinense. Itajaí: Herbário Barbosa Rodrigues. p. 1-173.

SEHNEM, A., 1977. As filicíneas do Sul do Brasil, sua distribuição geográfica, sua ecologia e suas rotas de migração. Pesquisas, vol. 31, p. 1-108.

SEHNEM, A., 1979. Semelhanças e diferenças nas formações florestais do sul do Brasil. Acta Biologica Leopoldensia, vol. 1, no. 1, p. 111-135.

SMITH, AR., KATHLEEN, MP., SCHUETTPELZ, E., KORALL, P., SCHNEIDER, H. and WOLF, PG., 2006. A classification for extant ferns. Taxon, vol. 55, no. 3, p. 705-731. http://dx.doi. org/10.2307/25065646.

SMITH, AR., PRYER, KM., SCHUETTPELZ, E., KORALL, P., SCHNEIDER, H. and WOLF, PG., 2008. Fern Classification. In RANKER, TA. and HAUFLER, CH. The Biology and Evolution of Ferns and Lycophytes. Cambridge: Cambridge University Press. p. 417-467.

STAUDT, MG., LIPPERT, APU., CUNHA, S., BECKER, DFP., MARCHIORETTO, MS. and SCHMITT, JL., 2012. Composição florística de epífitos vasculares do Parque Natural Municipal Tupancy, Arroio do Sal, RS - Brasil. Pesquisas, vol. 63, p. 177-188.

TEIXEIRA, MB., COURA-NETO, AB., PASTORE, U. and RANGEL-FILHO,ALR., 1986. Vegetação: as regiões fitoecológicas, sua natureza e seus recursos econômicos - estudo fitogeográfico. 
In Levantamento de Recursos Naturais. Rio de Janeiro, IBGE, vol. 33, p. 541-620.

TER STEEGE, H. and CORNELISSEN, JHC., 1989. Distribution and ecology of vascular epiphytes in Lowland rain forest of Guiana. Biotropica, vol. 21, no. 4, p. 331-339. http://dx.doi. org/10.2307/2388283.

The Angiosperm Phylogeny Group - APG, 2009. An update of the Angiosperm Phylogeny Group classification for the orders and families of flowering plants: APG III. Botanical Journal of the Linnean Society, vol. 161, no. 2, p. 105-121. http://dx.doi. org/10.1111/j.1095-8339.2009.00996.x.

WAECHTER, JL., 1986. Epífitos vasculares da mata paludosa do Faxinal, Torres, Rio Grande do Sul, Brasil. Iheringia, vol. 34, p. 39-49.
WAECHTER, JL., 1992. O epifistismo vascular na Planície Costeira do Rio Grande do Sul.São Carlos: Universidade Federal de São Carlos. 163 p. Tese de Doutorado em Ecologia e Recursos Naturais.

WAECHTER, JL., 1998. O epifitismo vascular em uma floresta de restinga do Brasil subtropical. Revista Ciência e Natura, vol. 20 , no. 4 , p. 43-66.

WAECHTER, JL., 2006. Diversidade epifítica ao longo de gradientes ambientais. In MARIATH, JEA. and SANTOS, RP. (Eds.). Os Avanços da Botânica no Início do Século XXI: Conferências, Plenárias e Simpósios do $57^{\circ}$ Congresso Nacional de Botânica. Porto Alegre, Sociedade Botânica do Brasil. p. 350-353.

YEATON, RI. and GLADSTONE, DE., 1982. The pattern of colonization of epiphytes on Calabash Trees (Crescentia alata HBK.) in Guanacaste Province, Costa Rica. Biotropica, vol. 14, no. 2, p. 137-140. http://dx.doi.org/10.2307/2387743. 